\title{
Temel Kaynaklardan Hareketle Türk Devlet Geleneğinde Meşruluğun Dayanakları ${ }^{{ }^{*}}$
}

\author{
İsmail GÖKTÜRK
}

Öğr. Gör., Kahramanmaraș Sütçü İmam Üniversitesi, İktisadi ve İdari Bilimler Fakültesi, Kamu Yönetimi Bölümü ismailgokturk@yahoo.com

Orcid ID: https://orcid.org/0000-0003-3465-0418

\section{Öz}

Devlet, batı siyasal anlayışında belli bir ülkede yerleşmiş halkın üzerinde egemen olan bir siyasal otorite olarak anlaşılmaktadır. Bir ülkede iktidara gelme ve iktidarın sürdürülebilirliği, o ülke üzerine yerleşmiş halkın kültüründen kaynaklanan meşruiyet anlayışına yönetimin uyması ile mümkün olabilmektedir. Bu günümüzde genelde anayasalarda vazedilen süreçlerle belirlenmiştir. Türk milli kültürünün devlet anlayışı Egemenden hareketle tanımlanan bir anlayış değil; aşağıdan yukarı doğru bir örgütlenmedir. Devlet, milletin töresini yürütmek üzere, kut kazanmış iktidarlar tarafindan yönetilen, milletin teşkilatlanmasıdır. Türk devlet geleneğinde meşruiyet bağlamında iki kavram öne çıkmaktadır: Töre ve Kut. Milleti ayakta tutan gücün töre olduğu; devletten önce geldiği Orhun Bengütaşları'ndan bugüne bilinir. Bir deyimimiz bunu çok güzel ifade eder, "il gider, töre kalır. Yani töre olduğu sürece devletin yeniden kurulabileceği, aslolanın töreyi korumak olduğu esas alınır. Devletin varlık sebebi de esasen töreyi yürütmektir. Törenin temel değerleri vardır. Adalet, ahlak, bilgelik, cömertlik, yiğitlik vb. değerleri şahsında meczedebilen kimse "kut" kazanmış sayılır. Kut kazanmak, liyakat kesbedebilmek veya layık olma erdemi şeklinde tanımlanabilir. Dolayısıyla Türk devlet geleneğinde meşruiyet kut kazanmak şeklinde tecelli eden, törenin öngördüğü değerleri taşımak ve sürdürmek esasına bağlanmıştır.

Anahtar Kelimeler: Devlet, Töre, Kut, Meşruiyet.

\footnotetext{
${ }^{1}$ Makale Geliş/Kabul Tarihi: 21.02.2020 / 07.09.2020

* Bu çalışma, 24-26 Aralık 1997 yılında Sakarya Üniversitesi İIBF tarafından düzenlenen "Siyasette ve Yönetimde Etik" başlıklı sempozyumda sunulan bildirinin makale olarak düzenlenmiș halidir.

Künye Bilgisi: Göktürk, İ. (2020). Temel Kaynaklardan Hareketle Türk Devlet Geleneğinde Meşruluğun Dayanakları. Kahramanmaraşs Sütçü İmam Üniversitesi Sosyal Bilimler Dergisi, 17 (2), 1079-1099. DOI: 10.33437/ksusbd.692693
} 


\title{
Bases of Legitimacy in Turkish State Custom with Reference to Primary Resources
}

\begin{abstract}
In western political perception, state is understood as political authority which is sovereign over the people settled in a specific country. Coming to and sustainability of power in a country can be possible if the government abides by people's legitimacy perception arising from of their culture. At the present time, this is usually determined with processes preached in constitutions. State understanding of Turkish national culture is not a perception defined with reference to "hegemon" but an organization structured bottom to top. State is organization of the nation which is ruled by governments gained "kut" in order to sustain "töre" (moral laws) of the nation. In Turkish state custom, two concepts become prominent in the context of legitimacy: Töre and Kut. It has been known from Orkhon Inscriptions to now that the power keeping the nation on it's feet is töre and the töre precedes state. A Turkish idiom expresses this beautifully: "Country goes, töre stays." In other words, it is grounded on that a state can be re-established as long as the nation has töre and what really matter is retaining the töre. Raison d'être of the state is essentially implementing the töre. The töre has basic values. A person who interiorized the values such as justice, morals, wisdom, generosity, bravery etc. in her/his personality is considered as gained kut. Gaining the kut can be defined as obtaining merit of virtue. Hence, legitimacy in Turkish state custom is based on basis of having and maintaining the values that the töre prescribes and that appear in the form of the kut.
\end{abstract}

Keywords: State, Töre, Kut, Legitimacy.

\section{GİRIŞ}

Toplumsal hedefleri gerçekleştirmek için toplumun desteğini almak bir zorunluluktur. Sosyal bütünleşme, fertlerin ve sosyal grupların dünya görüşleri arasındaki müştereklerin toplumdaki milli kültürle en üst seviyede uyuşmasıdır. Sosyal bütünleşmenin temelinde kültüre olan bağlllık ruhu vardır. (Erkal, Baloğlu; 1997: 240-242). 


\section{Göktürk Temel Kaynaklardan Hareketle Türk Devlet Geleneğinde...}

Kalkınma, gelişme, büyüme gibi kavramlarla ifadelendirilen hedefleri gerçekleştirmek isteyen iktidar ve iktidarın kullanılış biçiminin, toplumun ortak kanaati diyebileceğimiz meşruluk zeminine dayanması, herkes tarafından kabul edilebilecek bir gerekliliktir. Meşruluğun dayanağ 1 ise, toplumun insana, eşyaya, kurumlara bakışını belirleyen milli kültürün oluşturduğu tasavvurlardır.

Sosyal hayatın meseleleri, günümüzde toplumun kültürel değerlerinden soyutlanarak incelenmeye çalışılmaktadır. Bu durum, meselelerin çözümsüz kalmasındaki en büyük etkendir. Türk devlet yapısı da Batı'da iktidar ilişkilerinin tarihi seyri içinde ortaya çıkan kavramlarla açıklanmaya çalışılmaktadır. Oysa toplumun teşkilatlanmış şekli olan devlet, bu manada milli kültürle iç içedir.

Bu çalışmada Türk kültüründeki devlet anlayışını tespit edebilmek için temel kaynakları inceleme gerekliliğinden hareketle; temel kaynaklardaki devlet, egemenlik ve meşru iktidar anlayışları ele alınmıştır. Temel kaynak olarak, yöneticilerin anlayışlarını açılayan Orhun Bengütaşları ve Kutadgu Bilig; yönetilenlerin yönetim anlayışlarını yansıtan Türk Destanları ve Dede Korkut Hikâyeleri alınmıştır. Temel kaynaklarda siyasi iktidar karşılığı olarak kullanılan kağan, bey, gibi ifadeler aynen kullanılmıştır.

Çalışmada ayrıca, siyaset bilimcilerin geliştirdikleri meşruiyet teorilerinin Türk devlet geleneğini izahta yeterli olup olamadıkları ve Türk devlet geleneğinin özellik arz eden yönleri ele alınmıştır.

\section{TEMEL KAVRAMLAR}

\subsection{Devlet}

Devletin ülke, insan topluluğu ve iktidar olmak üzere üç ana unsur üzerine bina edildiği hususunda birleşen çağdaş siyaset bilimciler, kavramı "belli bir ülke üzerinde yerleşmiş, zorlayıcı yetkiye sahip bir üstün iktidar tarafından yönetilen bir insan topluluğunun meydana getirdiği siyasal kuruluş" olarak tanımlamışlardır (Kapani, 1989, 35).

Temel kaynaklarda yer alan "il" kelimesi devlet anlamında kullanılmıştır. Orhun Kitabelerine göre Türkler'in cemiyet yapısını şöyle tespit etmek mümkündür: Oguş (aile) - urug (aileler birliği) - boy (kabile) - bodun (boylar birliği) - il (devlet). Türkler, bilinen ilk zamanlardan beri devlet nizamı içerisinde yaşayan medenî bir topluluktur.

"Üstte mavi gök, altta yağız yer kılındıkta, ikisi arasında insanoğlu kılınmış. İnsanoğlunun üzerine ecdadım Bumin Kağan, İstemi Kağan oturmuş, oturarak milletimin ilini töresini tutuvermiş." (Öztürk, 1996: 66). Bu cümleden hareketle; 
insanoğlunun yaratılmasıyla Türk Milletinin devlet olarak varlığı aynı zamana rastlamaktadır. İl ve törenin birlikte ele alınması, bizi, Türklerde devletin köklü temellere dayandırıldığı, öteden beri devlet nizamı fikrinin hakim bir kanaat olduğu sonucuna götürmektedir.

"Üstte gök çökmedikçe altta yağız yer delinmedikçe senin ilini ve töreni kim bozabilir" anlayışı bize gösteriyor ki Türk Devleti kıyamet kopuncaya kadar devam edecektir. $\mathrm{Bu}$ anlayış, Türkler'de "Devlet-i ebed müddet” fikrinin olduğunu, ancak devletin devamının töre ile mümkün olduğu, töresiz devletin binlerce yıl devam etmesinin mümkün olamayacağı açık bir şekilde vurgulanmaktadır. Dede Korkut Destanları'ında geçen "Devletiniz devamlı olsun Hânım hey" vurgusu da "devlet-i ebed müddet" anlayışının bir yansımasıdır.

İl, Kaşgarlı Mahmud'un lûgatında "sulh" "barış" manasına kullanılmıştır. "İlci" barışçı demektir. Eski Türklerde devlet barış dininden olduğu için devlete de il adı verilirdi (Türkdoğan, s.136). "İlli budun idim, ilim amanım hani". Buradaki "barış" Kutadgu Bilig'teki "Halka huzur ve rahat sağlayacak bir nizam kur; sana hayır dua etsinler.” (KB* , b. 5491) cümlesinde olduğu gibi, toplum huzuru ve rahatı anlamina gelir.

Kutadgu Bilig'te devlet güneşe benzetilmiştir: Güneş dünya için ne kadar gerekli ve ebedi bir nesne ise, devlet de halk için o ölçüde gerekli bir sosyal kurumdur. Devlet başkanına "Gündoğdu" adının verilmesi, devletin vasıfları ile alakalı bir takım ipuçlarını da vermektedir: Güneşe bak küçülmez, bütünlügünü daima muhafaza eder; parlaklığı hep aynı şekilde kuvvetlidir (KB, b.825). Benim tabiatım da ona benzer doğruluk ile doludur ve hiçbir vakit eksilmez (KB, b.826).

İl; onlu sisteme dayalı ordu nizamı yolu ile merkezden idaresini mümkün kılan teşkilat sayesinde bir devlet başkanının sorumluluğu altında budunların ve boyların işbirliğinden oluşan; arazisi (uluş) ile, birleşmiş halkı (budun, kün) ile, müşterek idari ve hukuki nizamı (töre) ile yurdu koruyan ve milleti refah, huzur ve barış içerisinde yaşatan bir siyasi kuruluştur (Kafesoğlu, 1983: 221).

Devletin şartlarında ise istiklal (oksızlık), ülke (uluş), halk (kün) ve kanun (töre) yer alır. Çağdaş siyaset biliminin devlet tanımında, devletin unsurları arasında yer alan iktidar ya da hakimiyet unsuru, Türk devlet geleneğinde yardımcı unsur olarak görülmekte; devletin temeli "töre" ile vücut bulmaktadır (Kafesoğlu, 1983: 221).

Batı'da klasikleşmiş devlet tanımı "belirli bir coğrafya üzerinde fiziki şiddet kullanma tekelini meşru biçimde elinde bulunduran insan topluluğu" şeklindedir. Bir egemen güçten hareketle yukardan aşağıya doğru tanımlanan bu tanım, Türk

${ }^{*}$ Kutadgu Bilig 


\section{Göktürk Temel Kaynaklardan Hareketle Türk Devlet Geleneğinde...}

devlet anlayışını izah edememektedir. Türklerde devlet, aşağıdan yukarı bir teşkilatlanmadır. Devleti, milletin töresini, dirlikli yapısını sürdürmek; milletin ideallerini hayata geçirmek üzere milletin teşkilatlanması olarak tanımlamak mümkündür. Nitekim aileler birleşip boyları, boylar budunu, budunların birleşimi devleti meydana getirir. İstiklal marşımızda yer alan "Sönmeden yurdumun üstünde en son ocak" misrası da bu hakikati ifade etmektedir. Bir ocak yani bir aile varsa devlet var olacak demektir. Biz de devlet "Leviathan" yani şerrinden emin olunması gereken bir ejder, canavar değildir. Bilakis uğrunda göz kırpmadan ölüme gidilen kutsal bir olgudur. Devlete yönelik her tehdit, devletin kurucusu olan milletin fertlerine yönelmiş tehdit demektir. Nitekim Tunç ve Atılgan (2018:97)'ın yapmış olduğu çalışmada da ifade edildiği gibi, aziz milletimiz menfur 15 Temmuz hadisesinde sokaklara inmiş ve meydanlarda gösterdikleri dirayet sayesinde devletine yönelen tehdidi bertaraf etmiştir. Aynı hadisede Anayasalarda yazmasa da, millet töreden kaynaklanan bir anlayışla doğrudan egemenlik yetkisini kullanmış; devletin kurucu iktidarının doğrudan millet olduğunu göstermiştir.

\subsection{Töre}

Töre; sosyal hayatı düzenleyen mecburi kaideler bütünüdür. Ayrıca anayasa hükmünde değişmez ilkeleri de vardır (Kafesoğlu, 1983: 233).Töre geleneğe dayalı "yusun"dur, yani hukuktur. Fakat "yusun", kurultayın fikirleri ve kurucu Kağan'ın iradesi ile birlikte uygulanır. Bununla birlikte töre, bir kavmin yaptıklarının ve yarattıklarının bütünü, içtimai ve dini düzen, adetler ve inançlar olarak da ele alınmaktadır (Tunç ve Demir, 2018:552). Bu yönü ile Türk-İslam yönetim geleneğinde töre oldukça önem atfeden bir anlayışı ifade etmektedir.

Milleti ayakta tutan gücün töre olduğu Orhun Bengütaşları'na yazılmıştır. "Türk Milleti, öleceksin" vurgusunun s1kça yapıldığ 1 metinde yokoluştan kurtuluşun töreye uymakla, yani "Ötüken Ormanı'nda oturmak"la mümkün olacağ 1 ifade edilmiştir. Bu anlamıyla töre milli kültür anlamına da gelmektedir. Çünkü burada milleti ebedi kılmanın kültürü muhafaza ile mümkün olduğu, bunun yolunun ise (o dönem için) yabancı kültürlerden uzak durmaktan geçtiği belirtilmektedir.

Tanrı kâdirdir (ogan), adildir (köni); gerçek töreyi koyan O'dur; yarattı̆̆1 bütün mahluklara gücü yeter (KB, b. 3191) anlayış1 "törütgen" ile "törü" arasındaki ilişkiyi göstermektedir. Bilindiği gibi "törü" töre kelimesini, "törütgen" ise yaratmak kelimesini karşılamaktadır. Bu manada töreyi "türemişlerin riayet edeceği Tanrı Kanunları" olarak tarif etmek mümkündür. Gökler nasıl "Tanrı Buyruğu"yla bir nizam içerisinde dönüyorsa, her zerrenin bağlı olduğu bir fizik kuralı, bir tabî yasa varsa, bu tabîliğin yeryüzünde tatbiki olan sosyal düzen de "töre" ile vucûd buluyordu. Töre göklerin nizamıydı ve gök 
çökmedikçe yürüyecekti. "Ey Türk Milleti, üstte gök çökmedikçe, altta yağız yer delinmedikçe senin ilini ve töreni kim bozabilir” (Kültigin Kitabesi doğu yönü).

“Adalete istinad eden töre bu göğün direğidir. Töre bozulursa bu gök yerinde duramaz. Bu töre koyan beyler, hayatta bulunmasalardı, Tanrı yedi kat yerin nizamını bozmuş olurdu (KB, b. 3463 ve 3464)." cümlesinden de anlaşılacağ 1 gibi Türk Cemiyet Nizamı bir tabîlik etrafında şekillenmektedir. Törenin "Tanrı Kanunları" olarak görülmesi, törenin evrensel değerlere yaslanmasından kaynaklanmaktadır.

"Tanrı Buyruğu" kavramını, tabii olanla, insan fitratı ile alakalı açıklamak mümkündür. Bu noktada, insana ve insandan hareketle topluma, devlete bakıșta, Doğu ve Batı düşüncesindeki anlayış farkının ortaya konulması gerekmektedir. Sosyal ve siyasal yapılanmanın mihverinde insan vardır. Toplumların insan kavrayışı, toplumların sosyal ve siyasal yapılanmasının temelindeki esas faktördür. Türk devlet geleneğini belirleyen de yüksek Türk kültürünün insana verdiği değerdir.

Törenin bir takım temel değerleri vardır. Bunlar; eşitlik, akıl, bilgi ve hikmet, erdem, adalet, ahlâki değerler șeklinde sıralayabileceğimiz "törel değerler"dir. Çalışmanın bu bölümünde Doğu ve Batı düşüncesindeki anlayış farkını ortaya koyması açısından da yardımcı olacak bu değerleri gözden geçirmenin yerinde olacağı kanaatindeyiz.

Törel değerlerden ilki eşitliktir. Genelde kendi insanını sınıflara bölen Batı, kendi dışındakileri insandan bile saymaz. Türk Düşüncesi ise insanlar arasında fark gözetmez, dahası gözetmeyi yüz karası sayar. Hıristiyan Kilisesi insanı doğuştan günahkâr sayar, onu şuursuz ve aciz bir yaratık kabul eder. Böyle bir insanın din adamlarınca günahtan arındırılması ve Mesih'in ikinci gelişine hazırlanması lazımdır; vaftiz törenlerinin, itiraf merasimlerinin sebebi budur (Kezer, 1990: 52).

Batı Avrupa toplumlarında 20. Yüzyıl başlarına kadar "haklı"nın ortaya çıkarılması, ya da hakların iadesi için iki kişi arasında, şahitler huzurunda "güçlülük" mücadelesi yapılmıştır. Bu olayda (düello) usûl olarak yalnızca silahların eşitliği konusunda adaletin aranması ile yetinilmiş, hak ile güç ise anlamsız bir şekilde karşı karşıya getirilmiştir. Batılı düşüncede haklılık, kişisel vicdanlarda yerini güçlülük olayına bırakmışıı (Özbilgen, 1988: 127).

Machiavelli insanı şöyle tarif eder: İnsanlar genellikle nankör, değişken, ikiyüzlü, tehlikeden kaçan, çıkarlarında haris yaratılışlıdır; onların dostluğu para ile kazanılmıştır, gönül yüceliğiyle değil. İnsanlar yaratılıştan kötü oldukları için, bir çıkar karşısında sevgi bağları yok olur (Machiavelli, 1985: 80). İnsanların yaratılışları genellikle kötü olduğundan, ancak mecbur kaldıkları zaman iyi 


\section{İ. Göktürk Temel Kaynaklardan Hareketle Türk Devlet Geleneğinde...}

davranırlar, zorunlu olmadıkları zaman kötü olarak karşımıza çıkarlar (Machiavelli, 1985: 112).

Türk düşüncesinde ise insan yüce tutulmuştur; Tanrı insanı yarattı, seçerek yükseltti,; ona fazilet, bilgi, akıl ve anlayış verdi (KB, b.148). İster oğlum, ister yakınım veya hısmım olsun, ister yolcu, geçici, ister misafir olsun; Kağan'ın karşısında benim için bunların hepsi birdir, hüküm verirken hiçbiri beni farklı bulmaz (KB, b.817 ve 818).

Türk-İslâm dünya görüşü, insan haysiyetine büyük değer veren, bu haysiyeti, inancın ve düşüncenin tüm belirtilerinde görmesini bilen bir idraktir. Vazgeçilmez icapları adalet, eşitlik, hürriyet ve müsamahadır (Meriç, 1980: 263). $\mathrm{Bu}$ temel değerlerdir ki dünyanın en uzun ömürlü imparatorluklarını Türklere kurdurmayı nasip etmiş, Türk olmadıkları halde Türk yönetiminde huzur, barış ve adalet bulan tebânın da yönetime uyum sağlaması sonucunu doğurmuştur. $\mathrm{Bu}$ durum yönetime hakim olan törel değerlerin insani ve evrensel olduğunun göstergesidir.

Temel değerlerden biri de iyiliktir. İnsan ancak başkalarına yararlı olduğu ölçüde insandır. İnsana karşı insanlık göstermek insanlık şiarıdır. İnsanların iyisi, üstünü, başkalarına karşı her vakit insanca hareket edendir (Kezer, 1987: 67).

Seçilerek yaratılan insanın temel değerlerinden birisi de bilgidir; hikmettir. Asya Hunları'ndan bu yana bütün Türk tarihinde, siyaset ve idarede "hakim" anlamında "bilge" sıfatının idarecilerde aranan bir meziyet olduğu bilinmektedir. Bilge "hakim", bilgelik de "hikmet" yerine geçmektedir (Başer, 1990, 34). Tanrı insanı yarattı, seçerek yükseltti; ona fazilet, bilgi, akıl ve anlayış verdi. Bilgiyi büyük ve anlayışı ulu bil; seçkin kulu bu iki şey yükseltir (KB, b.148: 152).

Türk Hakanlarının kendileri bilge oldukları gibi, çevrelerinde de sürekli bilge kişileri bulundurmuşlardır. Yöneticilerin yanında daima bilge kişiler yer almıştır. Bu bazen Dede Korkut adıyla, bazen Hacip adıyla somutlaştırılmıştır. Nitekim İlteriş Kağan - Bilge Tonyukuk birlikteliğinde de bu vakıaya şahit olmaktayız: İlteriş Şad'ın Kağan olarak tanıtılmasında Bilge Tonyukuk'un kişisel gücü (bilgeliği) etkili olmuştur (Öztürk, 1996: 37): Andan sonra Tanrı bilgi verdiği için bizzat Kağan kıldım (Tonyukuk Abidesi güney yönü). İlerde daha geniş anlatılacağg gibi, Bilge Kağan Kitabesi doğu yönünde, bilgeliğin ve bilgesizliğin devlet ve millet hayatında doğurduğu sonuçlar işlenmiştir. Yine Kutadgu Bilig 301. beyitte "Kimde ak1l varsa o asil insan olur. Kimde bilgi varsa o beylik bulur" ifadesi de bilginin ne kadar belirleyici bir unsur olduğunu vurgulamaktadır.

İnsanın temel değerlerinden biri de erdemdir. Erdem karşı1lığı olarak fazilet kavramı da kullanılmaktadır. Erdem, tüm etik değerlerin insanın şahsında mündemiç olmasının bir ifadesidir. 
Turfan Yazmaları arasında bulunan atasözlerinden birinde "faziletli insan cevherle birdir, faziletsiz insan çizme içindeki taban astarı ile birdir." ifadelerine yer verilmiş; fazilet ya da erdemin önemi vurgulanmıştır.

Bir başka temel insani değer de; ahlâkî değerlerdir: "İnsan gönlünü çıkarıp avucuna koyarak başkaları önünde mahcup olmadan dolaşabilmelidir. Saadette yükselmek için insanda doğruluk lazımdır. İnsanlık doğruluğun adıdır inan. İnsan nadir değildir, insanlık nadirdir. İnsan az değil, doğruluk azdır. Kimin düşündüğü ile söylediği bir olursa işte doğru insan odur" ifadeleri ahlâkı oluşturan değerlerin önemine işaret etmektedir (KB, b. 864 - 867).

Dede Korkut Hikâyeleri'nde Kam Püreoğlu Bamsı Beyrek Destanı'nda yalan söyleyen kişi Yalancıoğlu Yaltacuk tiplemesi ile teşhir edilmiş ve dişlanmıştır (Ergin, 1980: 60).

Kutadgu Bilig'de hükümdarın hoşlanmadığı şeylerden şöyle bahsedilmektedir: Benim beğenmediğim şeylerden biri de yalandır. Ondan sonra zulüm edenler gelir. Sonra da haris tabiatlı ve olgun olmayan insanlar ile aceleci huylu ve gözü doymayan insanlar. Her işte hiddet gösterenler, içkiye düşkünler ve çalıp çırpanlar. Bu gibi insanlar bana yaramaz, işte sana bunları açıkça döküp saydım (KB, b. 848 - 851).

Törel değerlerden bir başkası da cömertliktir. Bey’e Cömertlik ve alçakgönüllülük lazımdır. O gözü tok, sabırlı, alçakgönüllü, şefkatli ve sakin tabiatlı olmalıdır (KB, b. 2040, 2170). Dede Korkut Destanı'nda alp olmanın şartlarını şu hitaptan anlamak mümkündür: Salur Kazan'ın divanında serbestçe oturan Eğrek'e, Ters Uzamış, kınayarak; "Bre Uşun Koca oğlu, bu oturan beyler, her biri oturduğu yeri, k1lıcıyla, ekmeğiyle almıştır, bre sen baş mı kestin, kan mı döktün, aç mı doyurdun, çıplak mı donattın" der (Ergin, 1980: 187).

Türk devlet geleneğinde törenin (hukukun) üç değişmez amacı vardı: Könilik (adalet), uzluk (iyilik, faydalılık), tüzlük (eşitlik) (Niyazi, 1996: 223).

Bizim toplumsal sistemimiz, devlette adalet; toplumda erdemlerin egemen olması ile vücut bulmuştur. Törenin en temel vasfı adalettir. Adalete istinad eden töre bu göğün direğidir. Töre bozulursa bu gök yerinde duramaz. Bu töre koyan beyler, hayatta bulunmasalardı, Tanrı yedi kat yerin nizamını bozmuş olurdu (KB, b. 3463, 3464).

Töre kavmin hakkıdır. Töre tüz yürürse cihan nizama girer (KB, b. 3108).

“Töreden saparsan bu zulüm olur. Zulüm saraylar harap eder. Zulüm yanar ateştir, yaklaşanı yakar; kanun sudur; akarsa nimet yetişir (KB, b. 2032 - 2033). 


\section{İ. Göktürk Temel Kaynaklardan Hareketle Türk Devlet Geleneğinde...}

Türk Devlet Geleneği'nin tüm merhalelerinde daire- i adliye olarak adlandırılan bir süreç vardır. Devletin varlığı ve bekâsı daire-i adliye ile ilişkilendirilmiştir. Memleket tutmak için çok asker ve ordu lazımdır. Askeri beslemek için de mal ve servete ihtiyaç vardır. Bu malı elde etmek için, halkın zengin olması, halkın zenginliği için de doğru kanunlar konulmalıdır. Bunlardan biri ihmal edilirse, dördü de kalır. Dördü birden ihmal edilirse beylik çözülmeye yüz tutar (KB, b. 2057, 2058).

Göktürk Yazıtları'ndan günümüze kadar yazılan yüzlerce siyasetnamede tekrar edilen ortak bir ifade vardır. O da "küfür ile bir ülkenin âbâd olabileceği; fakat zulüm ile asla iktidar olunamayacağı" hususudur.

Adalet, ferdi ve içtimai yapıda dirlik ve düzenliği, hakkaniyet ve eşitlik ilkelerine uygun yaşamayı sağlayan ahlaki erdemdir. Adalet, başkalarının gelişigüzel istek ve telkinlerinden etkilenmeyen istikrarlı bir doğruluk ve ahlak kanununa itaatla gerçekleşen ruhi denge ve ahlaki kemaldir. İslam düşüncesinde, kâinatın her alanında var olduğu kabul edilen nizam toplumsal düzende de aranmış ve cemiyetin sağlıklı bir şekilde işleyebilmesi, İbni Sina'nın deyişiyle "kanun ve adalet ilkelerine uygun düzenlenmesine bağlıdır. İnsanın fizyolojik ve fizyonomik yapısındaki uyum, ahenk ve estetik görünümden, atomlardan yıldızlara kadar evrenin işleyişindeki ahenk adalet kavramıyla açıklanmaktadır (Çağırıc1, 1988:341-342). Bu yönüyle adalet, evrensel tabii düzenin beşeri ilişkilere bir yansıması olup, sistemli bir bütündür. Adaletten en küçük sapma, bir nevi kıyamettir. iktidarın meşruiyeti, töreye uyduğu sürece devam eder, yoksa "kut” çekilir. "Adalete istinad eden töre bu gögün direğidir. Töre bozulursa bu gök yerinde duramaz. Bu töre koyan beyler, hayatta bulunmasalardı, Tanrı yedi kat yerin nizamını bozmuş olurdu (KB, b. 3463 ve 3464).”

Törenin diğer bir adı da yoldur. Her şey kalksa töre kalkmaz denilmiştir. Herkes bu yoldan gitmek zorundadır (Niyazi, 1996: 222). Günümüzde yolsuz, yolsuzluk olarak kullanılan kelime de, kanundan, töreden sapmayı ifade etmektedir.

Kutadgu Bilig'te devlet güneşe benzetilmiştir: Güneş dünya için ne kadar gerekli ve ebedi bir nesne ise, devlet de halk için o ölçüde gerekli bir sosyal kurumdur. Devlet başkanına "Gündoğdu" adının verilmesi, devletin vasıfları ile alakalı bir takım ipuçlarını da vermektedir: Güneşe bak küçülmez, bütünlüğünü daima muhafaza eder; parlaklığı hep aynı şekilde kuvvetlidir (KB, b.825). Benim tabiatım da ona benzer; doğruluk ile doludur ve hiçbir vakit eksilmez (KB, b.826).

Türk devlet geleneğinde meşru devlet/yönetim, halkın değer yargılarına yaslanan, halkın denetimine açık, töreyi yürüten, adaleti tesis ve tevzi eden bir 
yapılanmadır. Cahit Tanyol'un ifadesiyle "Anadolu halkı devlet deyince adaleti hakça bölüştüren devleti anlıyordu” (Tanyol, 2004: 20).

Gerek İslam düşüncesini oluşturan kaynaklarda, gerekse İslam öncesi Türk devlet geleneğini yansıtan referanslarda (yazıtlar, destanlar, vb.) devletin varlık nedeninin adaletin gerçekleştirilmesi olduğu; meşruiyetin ancak halkın inanç sistemine ve törel değerlerine (örf) dayanmakla sağlanabileceği görülmektedir. Eski Türk devlet geleneği ile İslami geleneğin mezcedilmesiyle ortaya çıkan siyasetnamelerde de bu hususlar vurgulanmıştır. Tarihimizdeki yönetim pratikleri de meşruiyet-adalet ilişkisini yansitan uygulamalar olmuştur. Siyaseti en iyi bilen hükümdar, meşruiyetini ve liderliğini halkının gönlüne taht kurarak pekiştirendir. Adalet için en ulu siyaset, en yüksek fazilettir diyebiliriz (Göktürk ve Y1lmaz, 2005: 312)

\subsection{Kut}

Kut, "mutluluk", "hakimiyet", "devlet kudreti" anlamlarını taşımaktadır. Kavram, hakimiyet ile mutluluğun ayrılamayacağını vurgularken bazen de "nasip", "devlet", "talih", "saadet" ve "uğur" kelimelerinin karş1lığı olarak kullanılmıştır. Deyimlerimizde de ifadesini bulduğu gibi, örneğin yere ekmek kırı̆̆ 1 dökmenin fakirlik alameti sayılması bir liyakat kespetmek bizim kültürümüzde çok değerlidir. Kut kavramını günlük dilde bayram kutlamalarında kullanmaktayız. Kut kavramı bu anlamıyla da herhalde günlerden bir gün olan bu gün senin için bayram olarak nitelenmeye değer bir gün kıymeti kazansın, mübarek kılınsın anlamında kullanılmaktadır. Siyaset sosyolojisi bağlamında "kut", liyakat kazanmak olarak değerlendirilirse, kavram karşıllı̆̆ olarak "layık olma erdemi” diyebiliriz.

Bütün bey ve büyüklere giden yol "kut"tan geçer. Kut, her türlü ululuğun kaynağıdır, arzu edilen her şey onun elinin altındadır (KB, b. 674,675). Saadet kime verilirse o kimse tevazu göstermeli ve alçak gönüllü olmalıdır. Kut aslında göç atı gibidir; göçer gider. Onu bulunduğu yerde tutan kökü alçakgönüllülüktür. (KB, b. 1702, 1704).

Kut, insandaki asli cevherdir. Kut, bu anlamiyla törel değerleri de kapsamaktadır. Kut nefsaniyetle, erdemsizlikle bir arada bulunmaz. Kut, halkın nazarında yapılan işin, tutulan yolun, toplumun kültürel yapısına ve değer yargılarına uygun bulunması anlamını taşır. Törel değerlerin tümünü şahsında taşıyan kişi bey olabilecek kişidir. Bu durum "kut kazanmak" şeklinde ifade edilir. Bu anlamda kut meşruiyetin gerek şartıdır.

\section{MEȘRULUĞUN DAYANAKLARI}

\subsection{Meşruiyet Kavramı}




\section{İ. Göktürk Temel Kaynaklardan Hareketle Türk Devlet Geleneğinde...}

Devletin temel unsurlarından biri olarak siyasi iktidar, teknik anlamıyla; "ülkenin ve toplumun bütünü üzerinde geçerli olan iktidar" karşılığı olarak kullanılmaktadır (Kapani, 1989: 48).

Siyasi iktidar, ülke üzerinde hiyerarşik olarak en üstün iktidar olma, maddi kuvvet ve zor kullanma gücü ile kendini gösterir. Teoride böyle olmasına rağmen, kuvvet kullanma, meşrulukla ters orantılı bir ilişki içerisindedir. Siyasi iktidarın belirleyicisi esasında rıza ve itaat unsurudur. Bugün, dünya üzerinde yönetilenlerin istek ve temayüllerini dikkate almayan devlet yok gibidir. Bundan dolayıdır ki siyaset biliminde karşılıklı etkileşimi ifade eden "iktidar ilişkileri" deyimi kullanılır olmuştur (Kapani, 1989: 51).

Kuvvetli olan kuvvetini hak şekline, itaati de vazife şekline sokmadıkça hiçbir zaman daima hakim kalacak kadar kuvvetli değildir (Rousseau, 1991: 6). Örneğin Roma'nın duvarları arasına, asırlarca hiçbir ordu ayak basmamıstı. Daimi görevliler yoktu. Yönetenlerin işlerini sadece "liktör" denilen birkaç adam görüyordu. İktidarın elindeki güç, topluluğun bütününden aldığ 1 güçtür (De Jouvenel, 1997: 44).

İktidar ilişkilerinin karşılıklı olduğu gerçeğinden hareketle siyasi iktidarın ayakta kalabilmesi için meşruluk zeminine oturması gerekmektedir. Yani siyasi iktidar, ona tâbi olanlar tarafindan meşru olarak kabul edilen, toplumda yaygın ve hakim olan meşruluk manasına uygun olmak zorundadır. Turfan Yazmaları arasında bulunan "Bey olmayacak kişi bey olursa, her yol kavşağına sopa koyar." atasözü bu gerçeği ifadelendirir (Arat, 1991: 275). Nitekim günümüzde meşruiyetini halkından almayan diktatörlüklerin ülkeleri yönetilemez duruma gelmiş, baskı ve zor kullanma rejimi sürdürülebilir olmaktan çıkmıştır.

Meşruluk; bir halkın haklı bulduğu, onayladığı, gönlünün razı olduğu durumdur. Meşru olan, toplumun zımni ya da açık kolektif tercihlerini yansıtan, onlara tercüman olandır. Bu anlamda meşruluk yasalardan kaynaklanabileceği gibi yasa ile ilgisi olmayan örf, adet, gelenek, hissiyat gibi hususlara da dayanabilir. Dolayısıyla meşruluğun hukuk çerçevesi ile sınırlandırılması mümkün olmayan, subjektifliğin hüküm sürdüğü, kültürün belirlediği bir alan olduğunun kabul edilmesi gerekmektedir (Vergin, 1996: 15).

Siyasi değerler, siyasi kültür, siyasi kurumlar, siyasi sistem ve siyasi güç arasındaki ilişkilerin tutarlı bir bileşkesinden oluşan siyasi meşruiyet, temelde siyasi gücün ortaya çıkış tarzının ve bu gücün uygulamalarının toplum tarafından anlamlı ve kabul edilebilir görülmesidir (Davutoğlu, 1995: 23).

Meşruluk, siyasal alanda iktidarın sağlanması ve elde tutulması bakımından yönetimi kolaylaştıran, sağlamlaştıran, daha istikrarlı ve etkili kılan çok önemli bir faktör olarak karşımıza çıkmaktadır. 
$\mathrm{Bu}$ noktada, sık kullanılmaya başlanmasının bir ülkede aslında bir rahatsızlı̆̆ın varlığını ifade eden "Temel Anlaşma (consensus)" dan söz etmek gerekir. Temel anlaşma, genel anlamıla; bir toplumda belli bir mesele üzerinde toplum üyelerinin büyük çoğunluğu arasındaki görüş birliğini ifade etmektedir. Siyasi alanda kullanımı ise toplumun yönetim düzeni, yani siyasal sistemi üzerinde anlaşmayı ifade eden bir kavram olmaktadır (Kapani, 1989: 86). Günümüzde ise bu anlaşma parlamentolar ve devlet başkanlarının halk tarafindan belirlenmeleri olarak kabul görmektedir (Ağır, 2017,174).

Egemenlik, çağdaş politika biliminde devletin unsurları arasında yer alırken, iktidar, egemenliğin kullanılış biçimini açıklar. Egemenlik sorunu, egemenliğin kaynağını içerirken, iktidarı kullanma, meşruluk sorununu beraberinde getirir.

\subsection{Egemenliğin Kaynağı Sorunu}

Günümüz siyasal iktidarlarının dayandığı temelleri araştıran temel teorilerin ilki "Klasik Teoriler” çerçevesinde incelenen "teokratik Teoriler” ve “demokratik Teoriler"dir.

Teokratik teoriler, en eski zamanlardan yakın zamanlara kadar egemenliğin kaynağının "ilahi” olduğu fikrinden hareket etmekteydiler; her türlü insan iradesinin üstünde, kaynağını "Ulu Yaratıı'nın karşı gelinemez mutlak iradesi”nden alan ve yine O'nun adına kullanılan bir iktidar şeklini ifade etmekteydi.

Demokratik teoriler ise "Milli Egemenlik Teorisi" ve "Halk Egemenliği Teorisi”nden oluşmaktadır:

Milli Egemenlik Teorisine göre; ülkede yaşayan insanların kişiliklerinden ayrı bir manevi kişiliği olan millet, egemenliğin tek meşru kaynağı ve sahibidir. Egemenlik, onu açıklayacak, ifade edecek bir iradenin varlığını gerektirir. Millet, fizikî bir varlığa sahip olmasa da bir "manevi kişi” olarak kendine özgü bir iradeye sahiptir. Egemenlik, bu milli iradede ifadesini bulur ve onun tarafindan seçilen temsilciler vasitasıyla kullanılır.

Milli Egemenlik Teorisi'nde, egemenliğin soyut bir bütün olarak kendisine manevi bir kişilik tanınan millete verilmesine karş1lık, Halk Egemenliği Teorisi'nde egemenlik somut olarak belli bir zamanda bir milli topluluğu oluşturan vatandaşlar kitlesine verilmektedir (Kapani, 1989: 70-74).

\subsection{Türk Devlet Geleneğinde Egemenlik}

Devletin Batı'da gelişme süreci sırasıyla "mülk devleti", "polis devleti" ve "hukuk devleti" şeklinde cereyan etmiştir. 


\section{İ. Göktürk Temel Kaynaklardan Hareketle Türk Devlet Geleneğinde...}

Bilindiği gibi “mülk devleti”, Ortaçağ'ın derebeylik sistemine dayanmaktadır. Hükümdarın hak ve yetkileri, derebeylerinin, kilisenin ve ayrıcalıklı kentlerin hak ve yetkileri ile sınırlandırılmıştır.

"Polis devleti"nin özelliği; yönetimin hukuk kurallarıla bağlı olmaması, güç ve yetkilerin takdire dayanmasıdır. "Polis Devleti"nin ayırt edici vasfı keyfi yönetimdir.

Kara Avrupası'nda, Fransız İhtilali'nden bu yana, "polis devleti” anlayışı yerini "hukuk devleti" anlayışına bırakmıştır. Yönetimin hukuka bağlı olması, Kara Avrupa'sı ülkelerinde "hukuk devleti”, Anglo- Amerikan ülkelerinde ise "hukukun egemenliği" yahut "hukukun üstünlüğü" kavramları ile ifade edilmektedir (Gözübüyük, 1992: 18-19).

Mutlak egemenliği olan yönetimlerden kurtulmak isteyen toplumların, egemenliği halka ya da millete vermeleri, politika biliminin eleştirilerine konu olmuştur.

Türk Devletlerinde egemenlik, devletin asli unsuru olmayip siyasi iktidar, otorite anlamında devletin mahiyetine içkindir.

Siyaset biliminin ana konularından olan egemenliğin kaynağı problemine Türk devlet geleneğinde rastlanmamaktadır, çünkü Türk devletinin temeli töreye dayanmaktadır.

Türk Hakanı, Yüce Tanrı'dan "kut" alır, böylece egemenliğe sahip olur. Ancak iktidarı mutlak değil, töreyle sınırlıdır. Başka bir deyişle iktidarın meşruiyeti, töreye uyduğu sürece devam eder, yoksa "kut" çekilir.

Türk devlet geleneğinde, mutlak egemenliği olan krallar hiçbir zaman var olmamıştır. Dolayısıyla "mülk devleti” ve "polis devleti" süreci Türk devletlerinde yaşanmamıştır. Bu anlamda Türk devletleri baştan beri "hukuk devleti” vasıflarını taşımaktadırlar. Orhun Bengütaşları'nda "töre” kelimesi onbir yerde geçmekte, bunun altısı "il" ile birlikte kullanılmaktadır. Kullanılan diğer beş yerde de "il" ile alakası açıkça bellidir. Türk Devleti, töre hükümlerine dayalı bir kuruluştu. Devletin varlığ "töre"nin varlığına bağlı idi. "Devleti ellerine alıp töreyi tesis ettiler” , "Ey Türk budunu senin ilini ve töreni kim bozabilir?”, "Devletini töresini terk etmiş", "O (İlteriş), atalarının töresine göre budununu teşkilatlandırdı", "Töre gereğince amcam tahta oturdu." (Kafesoğlu, 1983: 234).

Türk devletinde iktidarlar, "törenin yürütücüsü" olmuşlardır. Orhun Bengütaşları'na dikkat edilirse, hakimiyetle hakimiyeti elinde tutanların hatta hakimiyetle devletin ayrıldığı, Kağan'ın sadece hakimiyeti kullanan yüksek bir yetkili olduğu anlaşılmaktadır (Niyazi, 1996: 44). 
Kutadgu Bilig’de de "Memlekette uzun müddet hüküm sürmek istersen töreyi doğru yürütmeli ve halkı korumalısın" gibi beyitlerde, Bey'in töreyi yürütmekle memur olduğu vurgulanmaktadır.

Daha önce de belirtildiği gibi Türk devlet anlayışında, adalet yahut töreye sadakat, meşruiyeti sağlayan ilkedir. Eğer devlet başkanı töreden saparsa, kut yülek çekilir ve Kapağan Kağan gibi öldürülebilir, yerine erdemli Kağan geçirilir (Kösoğlu, 1997: 49).

Demokratik egemenlik teorileri, çağdaş politika bilimcileri tarafından, bazı noktalardan eleştirilmiştir. "Aslında bir düş ve kelime oyunundan başka bir şey olmayan” (Duverger, 1969: 8) demokrasi, tarihin hiçbir döneminde uygulanmamıştır. Demokrasi fikrinin kaynağı olan Roussaue'ye göre de demokrasi hiçbir zaman var olmamıştır ve olmayacaktır (Roussaue, 1992: 93).

Pratikte gerek halk egemenliği olsun, gerek millet egemenliği ilkesine dayansın seçim yöntemi ile işbaşına gelmek, demokratik ülkelerin geleneği olmuştur. Ülkemizde 1950 'den beri sürdürülen çok partili parlamenter sistem 2017 yılında yapılan referandumla başkanlık (cumhurbaşkanlığı) sistemine dönüştürülmüştür.

Yöneticilerin, halk tarafından sadece oy verilerek seçilmesi, Türk devlet geleneğinde yönetimin meşru kılındığı anlamına gelmemektedir. Demokrasi ile halka onaylatılan yönetimin meşruluğu esasen Türk kültür tarihinin derinliklerinde ifadesini bulan meşruluk ilkelerine uyduğu ölçüde meşru olabilecektir. Sadece bir yöntem olarak demokrasinin uygulanması, meşruluk zemininin oluşturulması için yeterli olamayabilecektir. Türk devlet geleneğinde, törenin milli kültür anlamını da ihtiva etmesi, halk iradesini de içeriyordu. $\mathrm{Bu}$ duruma, Manas'in Han seçilmesini örnek olarak verebiliriz (İnan, 1997: 14).

Çin tahakkümünden Manas'ın kahramanlıkları sayesinde kurtulan Kırgız Halkı, oybirliğiyle Manas'ı Han seçmektedir. Manas'ın Hanlığını meşru kılan, burada halkın seçiminden önce, Manas'ın toplumun meşruiyet anlayışlarına uygun düşmesidir.

Çağdaş toplumlarda en iyi yönetim modelinin "sosyal hukuk devleti" olduğu bilinmektedir. Yönetimin hukukla bağlı olması, yargı denetiminin sağlanması, yönetimin meşruluğu için yeterli şart değildir. "Töre"nin, başta verdiğimiz anlamları içinde yer alan kültüre uygunluk, insan fitratına uygunluk, tabî olma özellikleri yanında, bugünkü anlamıyla bir anayasa niteliği de taşır. Ancak töre, anayasa kabul edilmiş ve yönetim de hukuka bağlı olsa dahi, iktidar, aşağıda açıklanacak özellikleri taşımıyorsa yine meşru olmayabilecektir. 


\section{İ. Göktürk Temel Kaynaklardan Hareketle Türk Devlet Geleneğinde...}

Temel kaynaklarda, “kut”un ilâhî kaynaklı olması, hükümdarın Tanrı'dan kut alması gerektiği anlayışı, günümüz teokratik temelli devlet anlayışı ile asla bağdaşmamakta; Türk devlet geleneğinde, icraatlarıyla mâsun bir devlet adamına rastlanılmamaktadır. Aynı zamanda "icraatlarıyla sorumsuz devlet başkanı" ve yaptıklarının hesabını vermemeyi gerektiren "dokunulmazlık" anlayışına rastlanmamaktadır.

Töreye uygunluk ve belli erdemlerin şahsında toplanmış olmasıyla kazanılan "kut", bunlara aykırılık halinde geri gitmekte, dolayısıyla otorite meşruiyetini yitirmektedir. Burada "Tanrı'dan kut almak" toplumun moral değerlerine yaslanmak anlamında kullanılmıştır. Tanrı tarafından verilen, gerçekte otorite veya iktidar değil, otorite veya iktidara layık olma erdemidir. Bilge Kağan Kitabesi doğu yönünde, Kağan'ın görevlerini yerine getirmediği anda "kut toplamadı" denilerek tahttan indirildiği anlatılmaktadır. Kut, töreye uygunluk, törel değerleri şahsında toplamak ve layık olma erdemi gösterebilmektir.

Kutadgu Bilig'de yer alan "Ey dünyaya hakim olan, iyi hareket et, kut geldiği gibi gidebilir" (KB. b. 5086) ifadesi de aynı duruma dikkat çekmektedir.

"Kut"un Tanrı tarafından geri alınmasının anlamı, beyin moral değerlerden uzaklaşması ile meşruiyetini yitirmesidir.

Türk devlet geleneğinde, herhangi bir hükümet veya devlet şekli öngörülmemiş, "kut kazanmak" adı altında törenin öngördüğü değerlere sahip olmanın gerek ve yeter şart olduğu belirtilmiştir.

\section{4. İktidarın Meşruluk Temeline Göre Sınıflandırılması}

Teokratik ve Demokratik Teoriler, siyaset sürecine "olması gereken" açıdan bakmışlardır. Bu teorilere ek olarak, politika bilimi alanında, siyasal iktidarın meşruluk temellerine "olanı tespit" açısından yaklaşan Weber'in Otorite Tipolojisi ve Easton'un Sınıflandırması çalışmaları da mevcuttur. Weber, üç ayrı meşruluk tipolojisi geliştirmiştir. Bunlar; geleneksel (ananevi) otorite, kanuni (yasal) otorite ve karizmatik otorite tipleridir. Geneksel Otorite, eskiden beri yaşayan geleneklerin ve bu geleneklere uygun olarak, otoriteyi elinde bulunduranların meşruluğunun kutsal olduğu inancına dayanmaktadır. $\mathrm{Bu}$ anlayışta, kimin hükümdar olacağını gelenekler belirler; kudret ve yetki belirli kurallarla tespit edilmiş olmayıp, kanunlara değil geleneklerin tayin ettiği yöneticilere itaat edilir. Yöneticilerin verdiği emirlerin meşruluğunu belirleyen faktör emirlerin geleneğe aykırı olmamasına bağlıdır (Weber, 1995: 331- 352).

Weber, karizmatik otoriteyi; bir kişinin kutsallığına ya da kahramanlık gücüne veya örnek alınacak niteliklerine ve bu kişi tarafından oluşturulan düzene, diğer kişilerin, halkın tam bir teslimiyet içinde bağlanmaları sonucu ortaya çıkan 
otorite olarak tanımlamıştır. Karizmatik meşruluk ise, geleneklerden ve eskiden beri alışılmış davranışlardan değil, doğrudan doğruya iktidarı kullanan kişiden, kişide Tanrı vergisi olarak mevcut olduğu kabul edilen üstün vasıflardan kaynaklanmaktadır.

Kanuni Otoritede emir verme gücünü kullananlar, akılcı kurallara (kanuna, yasaya) uygun olarak davrandıkları sürece meşrudurlar. Kanuni meşruluk, çağdaş egemenlik anlayışı olup esasları önceden kanunlarla tespit edilmiştir ve hâkimiyet sınırları belirli yetkiler çerçevesinde kullanılmaktadır. Yönetilenler, iktidarı elinde bulunduranlara değil, akılcı yasalara itaat ederler (Weber, 1995: 318). Kanuni meşruluğun belirlenmesinde bir ülkenin bulunduğu coğrafyadan, ekonomik, sosyal, siyasal kültürel ve tarihsel temelli bir çok unsur etkili olabilmektedir (Ağır ve Baharçiçek, 2015: 49).

David Easton, fonksiyonel sınıflandırmaya gitmiştir. Easton'a göre meşruluk üç kaynaktan doğmaktadır. Bu kaynaklar; ideolojk kaynak, yapısal kaynak ve liderlerin kişisel nitelikleridir.

Eğer devletin dayandığı temel değerler, ilkeler ve güttüğü hedefler, yönetilenler tarafından benimseniyor, doğruluğuna ve geçerliliğine inanılıyorsa yönetim meşruluk kazanmaktadır; bu durumda meşruluğun kaynağı ideolojiktir. Eğer siyasal yapı ve onun işleyişini düzenleyen kurallar, yönetilenler tarafindan benimsenmişse, bu durum yönetimin meşruluğuna işarettir ve meşruluk yapısal kaynaktan beslenmektedir. Easton'un meşruluğun kaynağını liderlerin kişisel niteliklerine dayandırması hususunda ise kısaca şunlar söylenebilir: Weber'in karizma kavramını aşan, ondan daha kapsamlı bir sınıflandırmadır. Easton'a göre; hangi yoldan olursa olsun destek kazanmada etkili ve başarılı olmak esastır. $\mathrm{Bu}$ teoride tek liderin değil, daha çok alt düzey liderlerin meşruluk konusundaki rolleri vurgulanmıştır (Kapani, 1989: 93-94).

\subsection{Türk Devlet Geleneğinde Meşru İktidar}

Türk devlet geleneğinde iktidar olabilmek belli şartlara bağlanmıştır. Bey olabilecek kişi, töreye uygun hareket etmeli ve kut kazanmalıdır. Beyliğe giden yol "kut"tan geçer. Kut, insandaki asli cevherdir. Kut kazanmak için insanın, törenin öngördüğü erdemleri şahsında toplaması gerekir. Bütün erdemleri şahsında taşıyan bey, toplum nazarında töreyi yürütecek ve itaat edilmesi gereken kişidir.

Orhun Bengütaşları'nda Bumin ve İstemi Kağan'ın vasıfları sayılırken; “Bilge Kağanlar imiş, Alp Kağanlar imiş, buyrukları yine bilge imiş alp imiş" (Kültigin Abidesi doğu yönü) ifadelerine yer verilmiştir. Bilge Kağan'ın “Ölecek olan halk1 dirilttim, doğrulttum, çıplak kavmi elbiseli, fakir kavmi zengin kıldım” (Bilge Kağan Abidesi doğu yönü) şeklindeki ifadeleri de bugüne kadar gelmiş olan 


\section{Göktürk Temel Kaynaklardan Hareketle Türk Devlet Geleneğinde...}

"Devlet Baba" anlayışının yansımasıdır. Dede Korkut Destanı Boğaç Han Hikâyesi'nde Bayındır Han'ın Dirse Han'ı kara çadıra buyur etmesi üzerine Dirse Han: "Bayındır Han kılıcımda mı, soframda mı eksiklik gördü" diye şikâyet etmektedir. Kutadgu Bilig, beyin vasıflarını şöyle saymaktadır: Doğru sözlü olmak, memlekette töreyi devletle tatbik etmek, açı elli ve cömert olmak, halka karş1 şefkat göstermek, düşmana boyun eğdirmek, azimkâr ve cesur olmak ( KB, b. 5903, 5904, 5905). "Halk için beyin cesur ve kahraman olması iyidir, büyük işleri ancak bu meziyetler ile karşılamak mümkündür" (KB, b. 1961). "Halk için beyin seçkin olması lazımdır, özü sözü doğru ve tabiatı güzide olmalıdır" (KB, b. 1963). Kutadgu Bilig'de beyin vasıfları pek çok yerde işlenmiştir ve bir anlamda meşru bir yönetimin prototipi de çizilmiştir.

Türk Destanları'nda da kişinin bey olabilmesi için mutlaka kamu yararına bir kahramanlık göstermesi, yılın belirli zamanlarında yağma, toy ve şenlikler vasıtasıyla cömertliğini sergilemesi ve halka hesap vermesi, bilge ve alp kişilerden oluşmuş bir ekibinin olması ve "kut almak" şeklinde tecelli eden bir olağanüstülük taşıması gerekir. Bu olağanüstülük, törenin öngördüğü erdemlerin beyin şahsında bütününün en üst seviyede tecelli etmesi anlamını ifade etmektedir. Yoksa Batı düşüncesindeki, Yunan mitolojisinden kaynaklanan insanın kendi boyutları dışında ulaşamayacağı yerlere yüceltilmesi, insanüstü bir varlık haline getirilmesi anlamında değildir (Özbilgen, 1988: 104).

Törenin ana unsurlarını açıklarken değindiğimiz "törel değerler", beyin tabî vasıflarıdır. Bey, bu tabî vasıfları taşıdığı için karizmatik otorite tipiyle benzerlik arz etmektedir. Ancak Weber'in karizmatik egemenliğindeki meşruluk inanc1, doğrudan karizma sahibi yöneticinin kişiliğini oluşturan olağanüstülüklerden, yahut halkın yöneticiye atfettiği olağanüstü vasıflardan kaynaklandığ1 halde, Türk devlet geleneğinde karizma, "törel değerler"den kaynaklanır ve her beyde bulunması gereken tabî vasıflardır. Ayrıca bu durum meşruluğun esas kaynağını oluşturmaktadır.

Cumhuriyet dönemi devlet anlayışımızda da karizması olan liderlerin halk nezdinde konumunun daha yüksek olduğu gözlenmekte; bu vasıfların öne çıktığı yönetici tipinin kamuoyu tarafından olumlu karşılandığı görülmektedir. Kimi dönemlerde ise, demokrasinin yapısı gereği halkın oylarını almak ve halk nazarında meşruiyetini sürdürmek için, yöneticilerin makyavelist bir tutuma yöneldiklerine şahit olunmuştur. Machiavelli' in de ifade ettiği gibi halkın törel değerlerinin yöneticinin şahsında bulunması değil, bulunuyor gibi gösterilmesi esas ve zorunluluktur (Machiavelli, 1984: 83-86).

Düşünce adamımız Nurettin Topçu'nun ifadesiyle esasen, hiçbir rejim kendiliğinden mutlak surette ne iyidir, ne de fenadır. Esas olan onu kullanacak insanın ruh ve ahlâk yapısıdır (Topçu, 1969: 7). 
Törenin bir anlamı da milli kültür idi. Yönetim, milli kültür ideallerini gerçekleştirdiği ölçüde halkta meşruluk zemini bulacaktır. Bilge Kağan, içte aşsız, dışta donsuz düşkün ve perişan halk üzerine oturmuş, baba ve amcasının kazandığı milletin ad1-sanı yok olmasin diye gece uyumadan, gündüz oturmadan, küçük kardeşi Kültigin ve iki şadıyla birlikte ölesiye çalışmıştır (Bilge Kağan doğu yönü). Yine Göç Destanı'nda Yulun Tigin'in, oğlu Galı Tigin'e aldığı Çin prensesi karşıllğında kutlu kayayı vermesi, ülkede kıtlığa sebep olur ve uğursuzluk olarak telakki edilir (Ercilasun, 1985: 54).

Easton tarafından geliştirilen meşruluk sınıflandırmalarından ideolojik kaynak, Türk devlet geleneğinde halkın devlete ve yönetime bakışını izahta yardımcı olabilir. Oğuz Kağan Destanı'nda “Gök çadırımız, güneş tuğumuz olsun" şeklinde ifade edilen "Türk Cihan Hâkimiyeti" fikri de ideolojik bir kaynak olarak ele alınabilir; cesur yaratılışlı ve hürriyetine düşkün olan Türk insanının önüne, vasıflarına uygun bir ideal konmuştur.

\section{SONUÇ}

Önce "töre" vardı. Gökler nasıl Tanrı buyruğuyla bir nizam içerisinde dönüyorsa, göklerin nizamının yeryüzünde tatbiki olan sosyal düzen de, göksel inanışlar çerçevesinde oluşmuş töreyle vücut buluyordu. Töre göklerin nizamıydı ve gök çökmedikçe yürüyecekti.

Töre olup kut olmasa, olsa daha iyi. Kut gelip konmasa, beylik olabilmez. Beylik olmasa dirlik olabilmez. Bütün bunlar olmasa mutluluk olabilmez.

Türk devlet geleneğinin temel kavramlarından töre; sosyal hayatı düzenleyen, geleneğe dayalı 'mecburî' kaideler bütünüdür. Milleti ayakta tutan gücün töre olduğu Orhun Bengütaşları'na kazınmıştır: "Türk Milleti öleceksin" vurgusunun sıkça yapıldığı metinde; yok oluştan kurtuluşun töreye uymakla; milli kültürü korumak, yani "Ötüken Ormanı'nda oturmakla" mümkün olacağı ifade edilmiştir. Töre adalettir. "Zulüm yanar ateştir, yaklaşanı yakar; kanun sudur, akarsa nimet yetişir."

Kut, "mutluluk”, "hakimiyet”, "devlet kudreti" anlamlarını taşımaktadır. Kavram, hakimiyet ile mutluluğun ayrılmayacağını vurgularken, bazen de "nasip", "devlet”, "talih" kelimelerinin karşılığ 1 olarak kullanılmıştır. Bütün bey ve büyüklere giden yol kut'tan geçer. Kut, layık olma erdemidir. Kut insandaki aslî cevherdir. Kut kazanmak için insanın bütün erdemleri şahsında toplaması gerekir. Bütün erdemleri şahsında taşıyan bey, toplum nazarında töreyi yürütecek ve itaat edilmesi gereken kişidir.

Politika biliminin egemenlik ve iktidar sınıflandırmaları temel kaynaklarda çizilen iktidar prototipini açıklamada yetersiz kalmaktadır. Türk devlet 


\section{Göktürk Temel Kaynaklardan Hareketle Türk Devlet Geleneğinde...}

geleneğinde mutlak egemenliği olan iktidarlar olmayıp egemenliğin kaynăg 1 töredir. Yönetici, töreye uygun olarak iktidara gelir ve töreye uyduğu sürece iktidarını sürdürür. Türk devlet geleneğinde yönetim, töreyi yürütmede bir araç olarak görüldüğü için ayrıca bir yönetim şekli belirlenmesine ihtiyaç duyulmamıştır. Sadece yönetici olacak insanlarda yukarıda açıklanan "töreye uygunluk" ve "kut kazanma" gibi özellikler aranmıştır.

Temel kaynakların incelenmesinden çıkan diğer bir sonuç ise yöneticilerin görüşlerini açıklayan Orhun Bengütaşları ve Kutadgu Bilig ile toplumun muhayyilesini yansıtan, yönetilenlerin anlayışlarını gösteren Türk Destanları ve Dede Korkut Hikâyeleri’nde çizilen yönetici prototipinin uygunluk arz etmesidir. Devletiniz devamlı olsun Hânım hey!

\section{KAYNAKÇA}

Ağır, Osman (2017), “Türkiye'de Başkanlık Sistemi Tartışmaları”, Türkiye'de Siyaset ve Uluslararası İlişkiler Alanında Güncel Tartışmalar, Ed. Osman Ağır, Seçkin Yayıncılık, Ankara.

Ağır, Osman ve Abdulkadir Baharçiçek (2015), “Rusya Federasyonu'nda Demokrasinin Yerleş(e)memesinin Nedenleri”, Akademik Yaklaşımlar Dergisi, C.: 6 S.1, ss. 45-63

Arat, Reşit Rahmeti (1991), Eski Türk Şiiri, 3.b., Türk Tarih Kurumu Yay., Ankara

Başer Sait (1990), Kutadgu Bilig’de Kut ve Töre, Kültür Bakanlığ1 Yayınları, Ankara

Çağırıcı, Mustafa (1988). “Adalet” Maddesi, İslam Ansiklopedisi, 1. Cilt, Türkiye Diyanet Vakfı Yayınları, İstanbul.

Davutoğlu, Ahmet (1995), "Seçim Sistemleri ve Siyasi Meşruiyet”, Aksiyon, Say1 51, ss.23

De Jouvenel, Bertrand (1997), İktidarın Temelleri, Çev. Nejat Muallimoğlu, Birleşik Yayıncılık, İstanbul.

Duverger, Mourice (Tarihsiz), Siyaset Sosyolojisi, çev. Şirin Tekeli, Varlık Yayınları, İstanbul.

Ercilasun, A. Bican (1985), “Göç Destanı” içinde, Büyük Türk Klasikleri, 1. Cilt, Ötüken Neşriyat, İstanbul.

Ergin, Muharrem, Dede Korkut Kitabı, Boğaziçi Yay., 1980, İstanbul. 
Erkal, Mustafa; Baloğlu, Burhan ve Filiz; (1997). Ansiklopedik Sosyoloji Sözlüğü, Der Yayınları, İstanbul.

Göktürk İsmail; Y1lmaz Mehmet, (2005), “Türk Siyasetinin temel Etik Sorunu”, Düşünen Siyaset, Postmodernizm Sayısı, 21, ss. 297-323.

Gözübüyük, Şeref (1991), Yönetim Hukuku, 4.b, “ S” Yayınlar1, Ankara.

İnan, Abdulkadir , (1992), Manas Destanı, 2. b., No.2127, Milli Eğitim Bakanlığ1 Yayınları, İstanbul.

Kafesoğlu, İbrahim(1983) , Türk Milli Kültürü, Boğaziçi Yayınları, İstanbul.

Kapani, Münci (1989), Politika Bilimine Giriş, Bilgi Yayınevi, Ankara.

Kezer, Aydın (1987), Türk ve Batı Kültüründe Siyaset Kavramı, Kültür ve Turizm Bakanlığı Yayınları, Ankara.

Kezer, Aydın (1990), Türk ve Batı Kültürü Üzerine Denemeler, Kültür Bakanlığı Yayınları, Ankara.

Kösoğlu, Nevzat (1997), Devlet, Ötüken Neşriyat, İstanbul.

Machiavelli, Niccolo (1985), Hükümdar, 2.b., çev. Selahaddin Bağdatlı, Sosyal Yayınc1lik, İstanbul.

Meriç Cemil (1980), Kırk Ambar, Ötüken Yayıncılık, İstanbul.

Niyazi, Mehmed (1996), Türk Devlet Felsefesi, Ötüken Neşriyat, İstanbul

Özbilgen, Erol (1988), Mağlupların Zaferi, İnsan Yayınları, İstanbul.

Öztürk, Ali (1997), Ötüken Türk Kitâbeleri, Milli Eğitim Bakanlığı Yayınları, İstanbul.

Rousseau, J. J. (1992), Toplum Anlaşması, Çev. Vedat Günyol, Milli Eğitim Bakanlığı Yayınları, İstanbul.

Tanyol, Cahit (2004). Kuruluş ve Fetih Destanı, Pozitif Yayınları, İstanbul

Topçu, Nureddin (1969), Devlet ve Demokrasi, Hareket Yayınları, İstanbul.

Tunç, Ahmet ve Atılgan, Ali (2018), "Paralel Devlet Yapılanmasının (PDY) Kamu Kurumlarma Sirayeti ve Bürokratik Vesayet Darbesi”, Kahramanmaraş Sütçü İmam Üniversitesi Sosyal Bilimler Dergisi, (15), ss.79-104. 


\section{Göktürk Temel Kaynaklardan Hareketle Türk Devlet Geleneğinde...}

Tunç, Ahmet ve Demir, Gül (2018), “İbn-i Haldun'un Devlet Teorisi ve Yönetimine İlişkin Öngörülerinin Türk-İslam Devletleri Üzerinden Yorumlanması", Route Educational and Social Science Journal, 5(14), ss.547-561.

Parlatır, İsmail (1996), Güzel Yazılar-Oğuzdan Bugüne, Türk Dil Kurumu Yayınları, Ankara.

Türkdoğan, Orhan (1978), Türk Tarihinin Sosyolojisi-toplum Yapısı ve Sınıfsal Gelişim, Hasret Yayınları, Ankara.

Vergin Nur, "Siyaset, İlgisizleşme ve Türkiye'de Temsil Sorunu”, Türkiye Günlüğü, Sayı 38, Ocak- Şubat 1996, ss. 5-22.

Weber, Max (1995), Toplumsal ve Ekonomik Örgütlenme Kuramı, Çev. Özer Ozankaya, İmge Yayıncılık, Ankara.

Yusuf, Has Hacib (1991), Kutadgu Bilig, Çev. R. Rahmeti Arat, Türk Tarih Kurumu Yayınları, Ankara. 